\title{
THERAPEUTIC EFFICACY OF $\beta$-LACTAM AND AMINOGLYCOSIDE ANTIBIOTICS ON EXPERIMENTAL PNEUMONIA CAUSED BY KLEBSIELLA PNEUMONIAE B-54 IN DIABETIC MICE
}

\author{
Yoshiki Obana, * Takeshi Nishino and Teruo Tanino \\ Department of Microbiology, Kyoto Pharmaceutical University, \\ 5 Nakauchi-cho, Misasagi, Yamashina, Kyoto 607, Japan
}

(Received for publication February 18, 1985)

\begin{abstract}
The therapeutic efficacy of six $\beta$-lactam and aminoglycoside antibiotics were compared in diabetic mice with experimentally induced Klebsiella pneumoniae pneumonia. $\beta$-Lactams caused a reduction in the numbers of bacteria, with clearance of bacteria from the lungs of diabetic and normal mice. The effect in diabetic mice, however, was very poor. In contrast thereto, no remarkable difference was seen between diabetic and normal mice when treated with aminoglycosides. The concentration of the test antibiotics to the lungs in diabetic mice was lower than in normal mice. The aminoglycosides were more effective than the $\beta$-lactams. These data suggest that in treating acute and more chronic forms of pulmonary infection caused by $K$. pneumoniae in diabetic mice aminoglycoside antibiotics are particularly valuable, whereas $\beta$-lactams must be given in large quantities using multiple administrations.
\end{abstract}

It is a well known clinical axiom that patients with diabetes mellitus have an increased susceptibility to various bacterial and fungal infections. Infection remains one of the most serious complications of diabetes mellitus and the three most common sites of infection are the lungs, the skin and the urinary tract. Furthermore, experimental infections in animal with chemically-induced diabetes have shown increased susceptibility to various infection ${ }^{1 \sim 6)}$. On the contrary some other studies have shown no increased susceptibility to infection ${ }^{7,8)}$. The diabetic patient is more difficult to treat because of depression of the host defense functions against infection. Not much work has been reported for the treatment of bacterial infection in diabetic animals.

In this report, we have studied the response of alloxan-induced diabetic mice with pulmonary infection to selected antibiotics.

\section{Materials and Methods}

\section{$\underline{\text { Bacterial Strain }}$}

Klebsiella pneumoniae B-54 strain, supplied by Prof. K. Matsumoтo, Institute for Tropical Medicine, Nagasaki University, Nagasaki, Japan, was used in this study. This strain was maintained on nutrient agar slants (Nissui, Tokyo) at room temp.

\section{Antimicrobial Agents}

The antimicrobial agents were supplied by the following organizations: cefmenoxime, Takeda Chemical Industries, Ltd., Osaka; ceftizoxime, Fujisawa Pharmaceutical Co., Ltd., Osaka; cefotaxime, Hoechst Japan Ltd, Tokyo; latamoxef and gentamicin, Shionogi \& Co., Ltd., Osaka; and dibekacin, Meiji Seika Kaisha, Ltd., Tokyo. Solutions of antimicrobial agents were prepared freshly each day.

\section{Animals}

Std- $d d \mathrm{Y}$ male mice weighing 17 to $18 \mathrm{~g}$ were obtained from the Shizuoka Agricultural Cooperative Association for Laboratory Animals, Hamamatsu, and fed water and standard laboratory food. 
Method of Producing Diabetes

Mice were fasted overnight and given one intraperitoneal injection of $250 \mathrm{mg} / \mathrm{kg}$ of alloxan monohydrate (Kanto Chemical Co. Ltd., Tokyo) dissolved in sterile physiological saline immediately before use. Fasting was continued for another 4 hours after which the animals were returned to their ordinary pellet diet. Six days after alloxan injection, blood was collected from the retoorbital plexus after withholding food for 18 hours. Blood sugar levels of treated and control animals were estimated by the method of WERNER et $a l^{9}{ }^{9}$. Only those alloxan-treated mice with blood glucose ranging from 140 to $320 \mathrm{mg} / \mathrm{dl}$ were used in the experiments.

\section{In Vitro Antimicrobial Activity}

The minimum inhibitory concentrations (MICs) of antibiotics against $K$. pneumoniae B-54 were determined by the agar dilution method in sensitive test agar (Eiken, Tokyo). The MIC was defined as the lowest concentration of antibiotic inhibiting growth after overnight incubation at $37^{\circ} \mathrm{C}$. The bactericidal activity of $\beta$-lactam and aminoglycoside antibiotics in vitro was determined in heart infusion broth (Nissui, Tokyo). In brief, stock culture was grown for 18 hours at $37^{\circ} \mathrm{C}$ in heart infusion broth and subsequently diluted with the same medium to a cell density of approximately $10^{7}$ $\mathrm{cfu} / \mathrm{ml}$. Aliquots of $9.0 \mathrm{ml}$ of this inoculated medium were transferred to flasks. The flasks were placed in a water bath at $37^{\circ} \mathrm{C}$ and $1.0 \mathrm{ml}$ of medium containing 10 -fold the desired initial concentration of antibiotics were added. The flasks were incubated at $37^{\circ} \mathrm{C}, 0.5 \mathrm{ml}$ aliquots were removed at intervals, diluted in saline, and plated for viable cell count determination. Colonies were counted after 24 hours of incubation at $37^{\circ} \mathrm{C}$ and the number of viable bacteria in the samples was estimated.

\section{Bactericidal Activity In Vivo}

Experimental pneumonia was induced by the aerosol method as described by NisHi $e t$ al. ${ }^{10)}$ with slight modification. For this purpose, $K$. pneumoniae B-54 was grown on nutrient agar for 18 hours at $37^{\circ} \mathrm{C}$ and cells harvested from the slant were suspended in nutrient broth (Nissui) to give a final cell density of $c a .10^{9} \mathrm{cfu} / \mathrm{ml}$. The test antibiotics were administered subcutaneously at 15 hours after infection of the mice. At intervals, animals were bled to death and their lungs were removed asceptically. The lungs were homogenized in saline, and dilutions were plated for colony counts.

\section{Concentration of the Antibiotics in the Lungs}

The test antibiotics were administered by subcutaneous routes in single doses of $125 \mathrm{mg} / \mathrm{kg}(\beta-$ lactam antibiotics) and $100 \mathrm{mg} / \mathrm{kg}$ (aminoglycosides) each to four mice infected with $K$. pneumoniae. Concentrations in the lungs were determined microbiologically by a disk plate assay method with Proteus mirabilis ATCC 21100 as test strain for $\beta$-lactams and with Staphylococcus epidermidis KP-1 for aminoglycosides.

\section{Results}

\section{In Vitro Antimicrobial Activity}

The MICs of $\beta$-lactams and aminoglycosides against $K$. pneumoniae are shown in Table 1 . The MICs were $0.025 \mu \mathrm{g} / \mathrm{ml}$ for cefmenoxime and cefotaxime, $\leqq 0.006 \mu \mathrm{g} / \mathrm{ml}$ for ceftizoxime, $0.05 \mu \mathrm{g} / \mathrm{ml}$ for latamoxef, and $0.39 \mu \mathrm{g} / \mathrm{ml}$ for gentamicin and dibekacin with inoculum sizes of $10^{6} \mathrm{cfu} / \mathrm{ml}$. In vitro bactericidal activities of the antibiotics shown in Fig. 1. Significant reduction in the number of surviving bacterial cells was observed at $0.04 \mu \mathrm{g} / \mathrm{ml}$ of cefmenoxime, cefotaxime, and latamoxef and at $0.008 \mu \mathrm{g} / \mathrm{ml}$ of ceftizoxime with initial cell densities of $10^{7} \mathrm{cfu} / \mathrm{ml}$. On the other hand, obvious 
Fig. 1. Effect of $\beta$-lactams and aminoglycosides on the viability of Klebsiella pneumoniae B-54.

- Control, $\bigcirc 0.008 \mu \mathrm{g} / \mathrm{ml}, \Delta 0.04 \mu \mathrm{g} / \mathrm{ml}, \Delta 0.2 \mu \mathrm{g} / \mathrm{ml}, \nabla 1 \mu \mathrm{g} / \mathrm{ml}, \nabla 5 \mu \mathrm{g} / \mathrm{ml}$.

Cefmenoxime

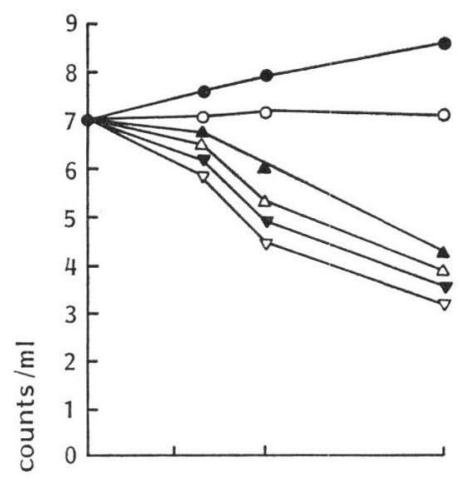

Ceftizoxime

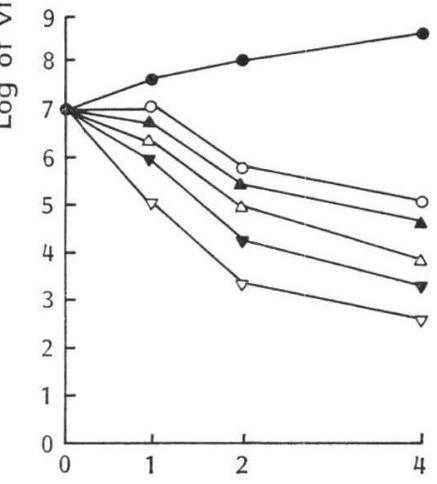

Cefotaxime

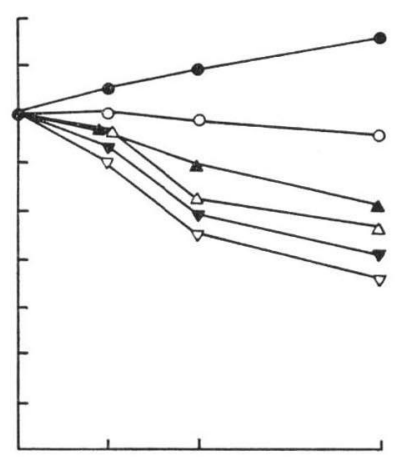

Latamoxef

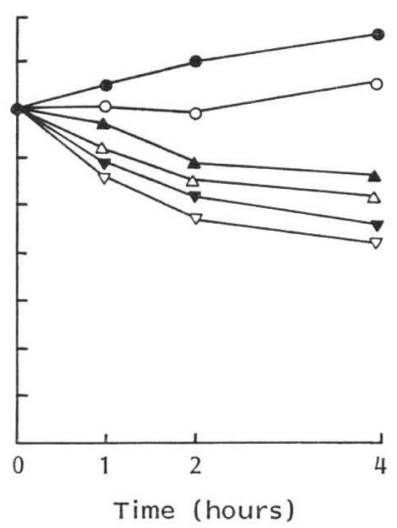

Gentamicin

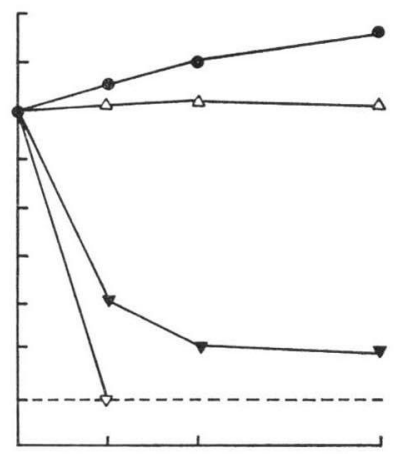

Dibekacin

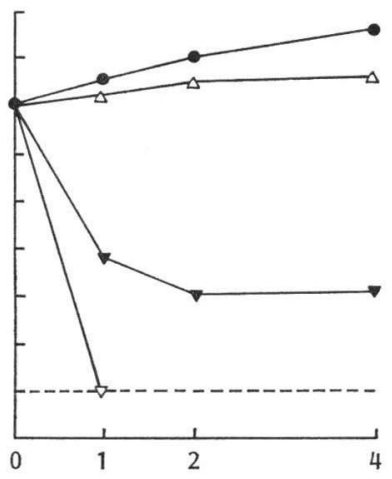

bactericidal effects of gentamicin and dibekacin were seen at first with $1 \mu \mathrm{g} / \mathrm{ml}$, but not with $0.2 \mu \mathrm{g} / \mathrm{ml}$. However, the bactericidal effects of aminoglycosides occurred faster than those of the $\beta$-lactams, especially during the first hour.

\section{Bactericidal Activity In Vivo}

\section{Single Administration}

The results of protection tests against experimental pneumonia in mice are shown in Table 2 . In significant numbers of normal mice $\beta$-lactams caused a reduction of bacterial cells, with clearance of the organisms from the lungs at $125 \mathrm{mg} / \mathrm{kg}$ or more. In diabetic mice, the reduction by $\beta$-lactams of bacterial cells in the lungs, obtained by a dosage of 125 to $250 \mathrm{mg} / \mathrm{kg}$ occurred to a much lower extent than in normal mice. Aminoglycosides caused a clearance of bacteria from the lungs already at $25 \mathrm{mg} / \mathrm{kg}$ or more and no remarkable difference was seen between diabetic mice and control mice.

\section{Multiple Administration}

The efficacies of cefmenoxime and ceftizoxime in multiple administration are shown in Figs. 2 and 3. The test antibiotics were administered once, twice, and three times with a two-hour interval between the doses. On the basis of the times of administration, $\beta$-lactams caused reduction in the numbers of bacteria in the lungs, with clearance of bacteria from the lungs, and supression of regrowth in 
Table 2. Therapeutic efficacies of $\beta$-lactams and aminoglycosides after subcutaneous administration on the number of bacteria in the lung of normal and diabetic mice infected with Klebsiella pneumoniae B-54 by the aerosol method.

\begin{tabular}{|c|c|c|c|c|c|c|c|c|c|}
\hline \multirow{3}{*}{\multicolumn{2}{|c|}{ Drug (mg/kg) }} & \multicolumn{8}{|c|}{ Log of viable counts/lung, hour after administration } \\
\hline & & \multicolumn{4}{|c|}{ Normal mice } & \multicolumn{4}{|c|}{ Diabetic mice } \\
\hline & & 0 & 4 & 24 & 48 & 0 & 4 & 24 & 48 \\
\hline \multirow[t]{3}{*}{ Cefmenoxime } & 250 & - & 2.83 & 2.00 & 2.53 & - & 3.95 & 5.52 & 7.00 \\
\hline & 125 & - & 3.36 & 4.00 & 4.64 & - & 4.67 & 6.59 & 7.68 \\
\hline & 62.5 & - & 4.07 & 6.03 & 8.01 & - & 5.06 & 7.11 & 8.03 \\
\hline \multirow[t]{3}{*}{ Ceftizoxime } & 250 & - & 2.87 & 2.22 & 2.84 & - & 3.11 & 4.09 & 6.02 \\
\hline & 125 & - & 3.45 & 3.22 & 4.10 & - & 4.02 & 4.99 & 7.15 \\
\hline & 62.5 & - & 4.08 & 5.01 & 7.23 & - & 4.98 & 6.70 & 7.81 \\
\hline \multirow[t]{3}{*}{ Cefotaxime } & 250 & - & 3.00 & 4.52 & 6.00 & - & 4.00 & 6.45 & 7.85 \\
\hline & 125 & - & 3.50 & 4.85 & 7.01 & - & 4.50 & 6.75 & 8.20 \\
\hline & 62.5 & - & 4.45 & 6.23 & 8.00 & - & 5.56 & 7.11 & 8.48 \\
\hline \multirow[t]{3}{*}{ Latamoxef } & 250 & - & 2.01 & 3.03 & 6.48 & - & 3.00 & 6.02 & 7.48 \\
\hline & 125 & - & 2.45 & 4.50 & 7.98 & - & 3.52 & 6.99 & 8.48 \\
\hline & 62.5 & - & 3.52 & 6.80 & 8.10 & - & 4.52 & 7.30 & 8.70 \\
\hline \multirow[t]{3}{*}{ Gentamicin } & 100 & - & 1.00 & 1.03 & 1.48 & - & 1.40 & 1.55 & 2.03 \\
\hline & 50 & - & 2.02 & 2.48 & 3.03 & - & 2.48 & 2.80 & 3.20 \\
\hline & 25 & - & 2.88 & 2.93 & 5.00 & - & 3.21 & 3.75 & 5.65 \\
\hline \multirow[t]{3}{*}{ Dibekacin } & 100 & - & 2.00 & 2.03 & 2.65 & - & 1.85 & 1.57 & 1.98 \\
\hline & 50 & - & 2.15 & 2.59 & 4.85 & - & 2.13 & 2.11 & 5.60 \\
\hline & 25 & - & 2.98 & 4.30 & 6.03 & - & 2.48 & 3.30 & 6.00 \\
\hline \multicolumn{2}{|c|}{ Untreated control } & 5.58 & 5.68 & 7.68 & 8.26 & 6.04 & 6.24 & 8.04 & 8.50 \\
\hline
\end{tabular}

Each value represents the mean of five mice.

Fig. 2. Therapeutic efficacy of cefmenoxime on number of bacteria in the lung of normal and diabetic mice infected with Klebsiella pneumoniae B-54 by the aerosol method.

Each value represents the mean of five mice.

$\bigcirc$; Normal mice, ; diabetic mice.
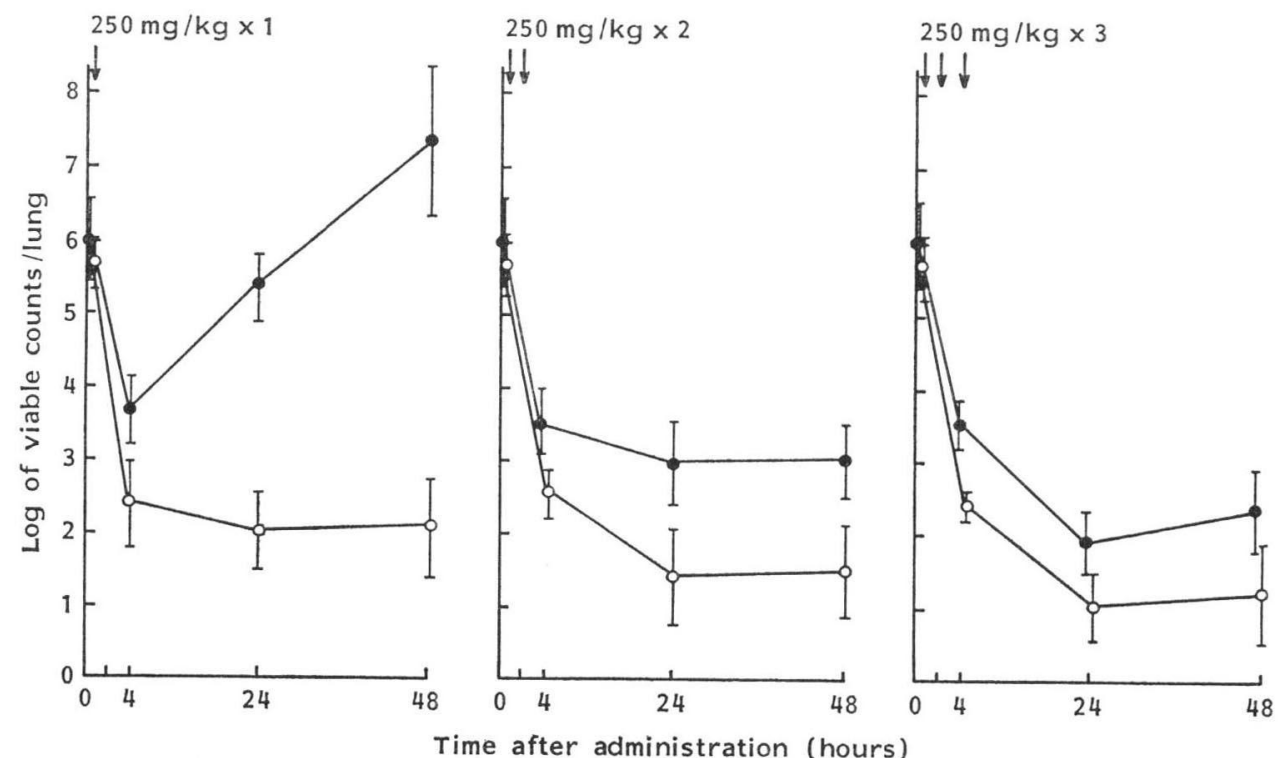

Time after administration (hours) 
Fig. 3. Therapeutic efficacy of ceftizoxime on number of bacteria in the lung of normal and diabetic mice infected with Klebsiella pneumoniae B-54 by the aerosol method.

Each value represents the mean of five mice.

○; Normal mice, ; diabetic mice.
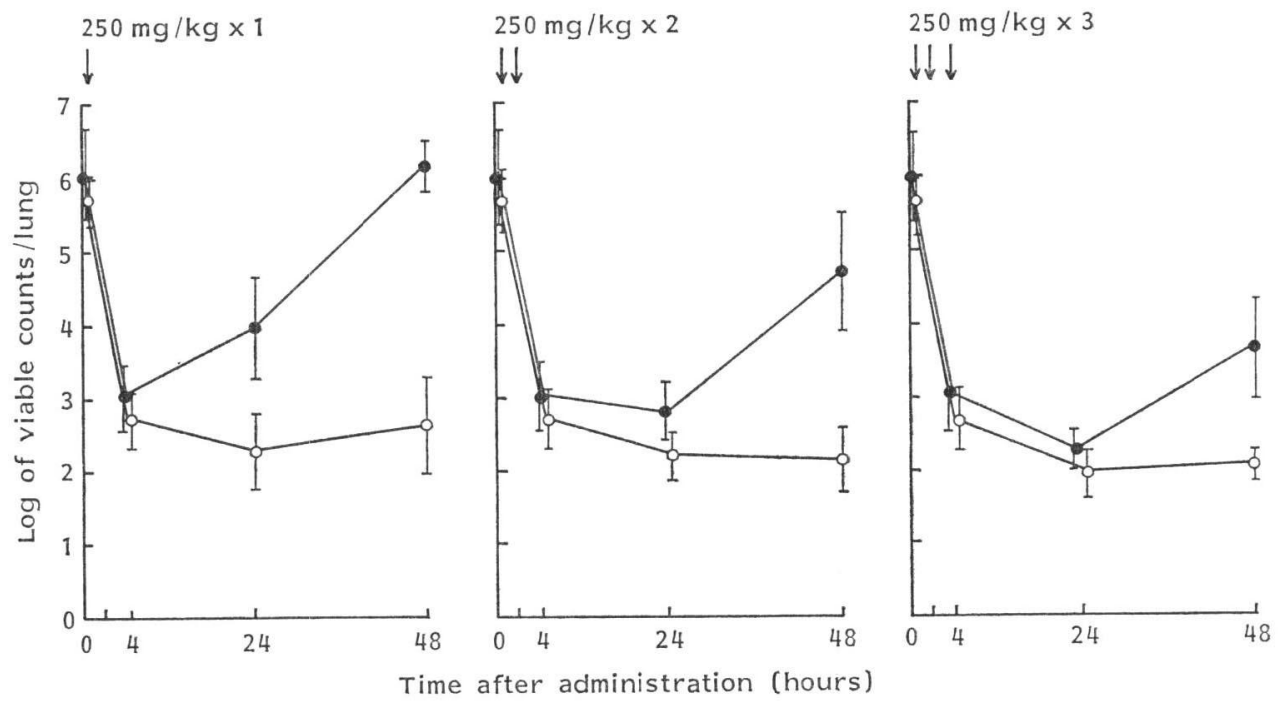

Fig. 4. Lung concentration of several antibiotics after subcutaneous injection to normal and diabetic mice infected with Klebsiella pneumoniae B-54 by the aerosol method.

O; Normal mice, ; diabetic mice.

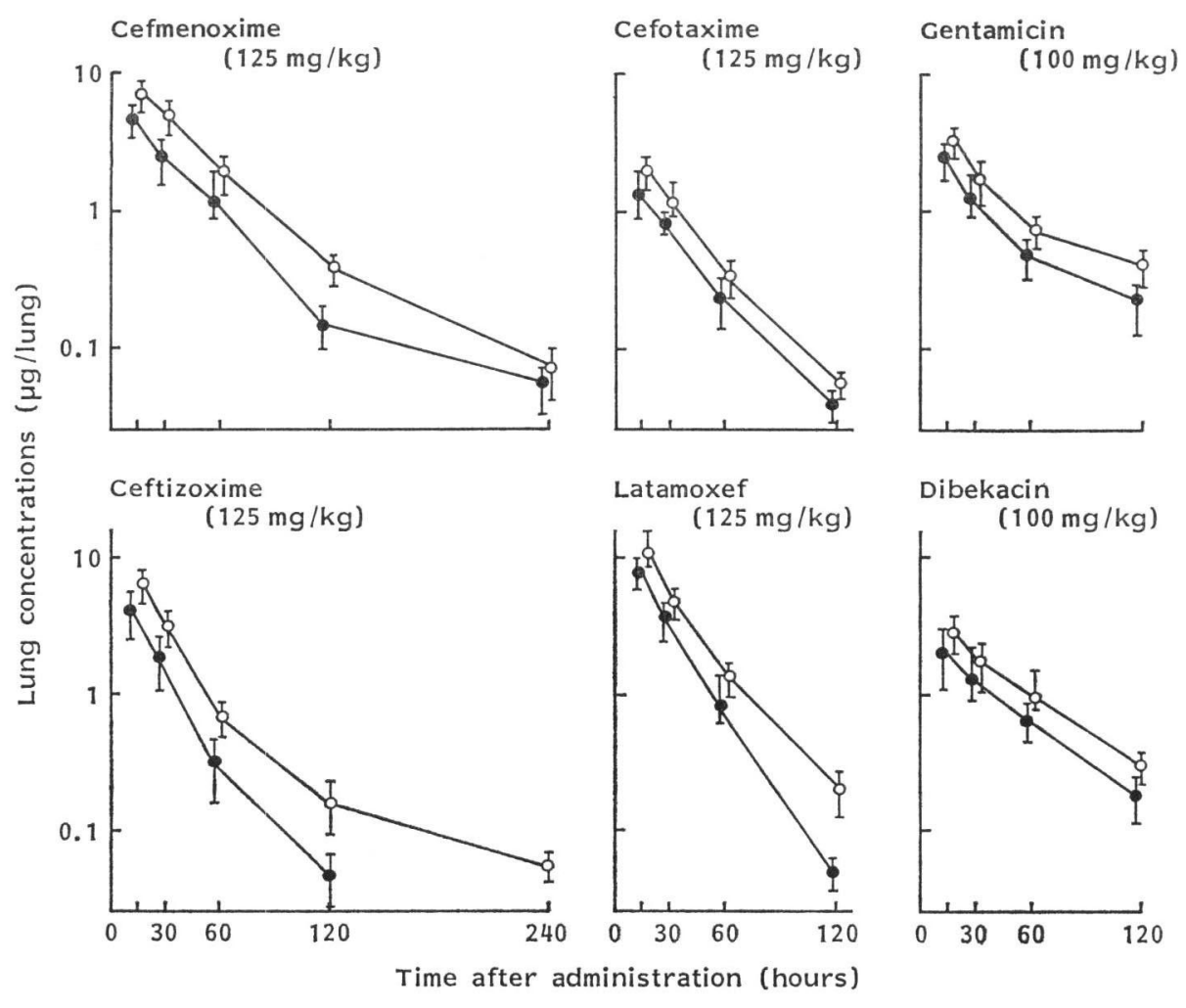


the lungs. The efficacy of a single administration in normal mice was equivalent to the efficacy of three times administration in diabetic mice.

\section{Lung Concentrations}

The mean lung concentrations obtained after $125 \mathrm{mg} / \mathrm{kg}$ of $\beta$-lactams and $100 \mathrm{mg} / \mathrm{kg}$ of aminoglycosides are shown in Fig. 4. A mean peak level was obtained 15 minutes after application and there was an initial rapid distribution phase followed by a gradual and steady decline. The mean peak level in diabetic mice, however, was only 70 to $80 \%$ of that of normal mice.

\section{Discussion}

Although much work has been done to investigate bacterial and fungal infections in animals with alloxan and streptozotocin induced diabetes mellitus, few reports are available on treatment of bacterial infections. In this paper, the therapeutic efficacy of $\beta$-lactams and aminoglycosides in diabetic mice were evaluated. On the basis of the dose-response relationship, $\beta$-lactams caused a reduction in the number of bacteria, with clearance of $K$. pneumoniae from the lungs of diabetic and normal mice. A remarkable difference was however seen between the effect in diabetic mice and that in normal mice, elimination of bacteria from the former being very poor. This might be due to the lower distribution of parenteral drugs in the lungs of diabetic mice (Fig. 4). Following treatment of animals with aminoglycosides, there was remarkably no difference in clearance of bacteria from the lungs between normal and diabetic mice (Table 2), though the distribution of these antibiotics to the lungs was shown to be as low as in the case of $\beta$-lactams. The obvious advantage of aminoglycosides seems to depend on their faster and stronger bactericidal activity, as this was observed in vitro (Fig. 1). Nevertheless, the side effects and toxicity of these compounds must be kept in view. $\beta$-Lactam antibiotics are known to cause the development of filamentous cells over a wide range of relatively low concentrations. Since filamentous cells are able to resume cell division and growth after removal of the antibiotics, the poor in vivo activity of $\beta$-lactams in diabetic mice might be attributed to a combined disadvantage of the low distribution characteristic and low bactericidal activity of the compounds. Some workers ${ }^{11213}$ ) reported that after treatment with $\beta$-lactams, such as sulbenicillin, cefuroxime, and ceftizoxime, the filamentous cells were more susceptible to non-specific host defense functions, such as serum and neutrophils, than the normal cells, and were easily cleared. It is unlikely that the host defense functions would be as efficient for these filamentous cells in an abnormal physiological condition such as diabetes mellitus ${ }^{14 \sim 18)}$. This may account for the poor therapeutic efficacy in diabetic mice. It has been reported that an important factor determining the efficacy of $\beta$-lactams is the total duration of the effective concentration ${ }^{19}$. Therefore, these antibiotics must be applied in large quantities and in multiple administrations. Moreover, regarding diabetes mellitus it is necessary to study chemotherapy in diabetic hosts. We are currently investigating these problems.

\section{References}

1) Andriole, V. T. \& H. F. Hasenclever: Factors influencing experimental candidiasis in mice. 1. Alloxan diabetes. Yale J. Biol. Med. 35: 96 112, 1962

2) Drachman, R. H.; R. K. Root \& W. B. Wood: Studies on the effect of experimental nonketotic diabetes mellitus on antibacterial defense. 1. Demonstration of a defect in phagocytosis. J. Exp. Med. 124: 224 240, 1966

3) Hurley, R.: Experimental infection with Candida albicans in modified hosts. J. Path. Bacteriol. 92 : $57 \sim 67,1966$

4) Mukherji, A. K. \& K. C. Basu Mallik: Candida albicans infection in alloxan induced diabetic mice. Indian J. Med. Res. 63: 539 544, 1975

5) Sood, U.; D. S. Agarwal \& A. L. Aurora: A study of subcutaneous staphylococcal infection in alloxan diabetic mice. Indian J. Med. Res. 63: 1564 1576, 1975

6) Raffel, L.; P. Pitsakis, S. P. Levison \& M. E. Levison: Experimental Candida albicans, Staphylococcus 
aureus, and Streptococcus faecalis pyelonephritis in diabetic rats. Infect. Immun. 34: 773 779, 1981

7) Cruickshank, A. H.: Resistance to infection in the alloxan-diabetic rabbit. J. Path. Bacteriol. 67: $323 \sim 334,1954$

8) Schofield, R. A. \& R. D. BAKer: Experimental mucormycosis (rhizopus infection) in mice: failure of chronic alloxan diabetes mellitus to modify host susceptibility. Arch. Pathol. 61: 407 415, 1956

9) Werner, W.; H. G. Rey \& H. Wielinger: Properties of a new chromogen for the determination of glucose in blood according to the GOD/POD (glucose oxidase-peroxidase) method. Fresenius' Z. Anal. Chem. 252: $224 \sim 228,1970$

10) Nishi, T. \& K. TsuchiYA: Experimental respiratory tract infection with Klebsiella pneumoniae DT-S in mice: chemotherapy with kanamycin. Antimicrob. Agents Chemother. 17: 494 505, 1980

11) Obana, Y. \& S. NAKazawa: Characters of Pseudomonas aeruginosa treated with sulbenicillin. Jpn. J. Bacteriol. 32: 337 343, 1977

12) Okumura, K.; T. Yokota, H. Kato \& H. Tsuj: Effects of cefuroxime and other cephalosporins on opsonification of serum and phagocytosis of polymorphonuclear leukocytes to $E$. coli. Chemotherapy 27: $76 \sim 82,1979$

13) Yокота, T. \& R. Sekiguchi: Ceftizoxime (CZX), a novel cephalosporin with high affinity for penicillinbinding protein $1 \mathrm{~b}$ of Escherichia coli and Vibrio cholerae (biotype EL TOR). Chemotherapy 28: 44 49, 1980

14) Bybee, J. D. \& D. E. Rogers: The phagocytic activity of polymorphonuclear leukocytes obtained from patients with diabetes mellitus. J. Lab. Clin. Med. 64: 1 13, 1964

15) Mowat, A. G. \& J. BAum: Chemotaxis of polymorphonuclear leukocytes from patients with diabetes mellitus. N. Engl. J. Med. 284: 621 627, 1971

16) Badgdade, J. D.; R. K. Root \& R. J. Bugter: Impaired leukocyte function in patients with poorly controlled diabetes. Diabetes 23: 9 15, 1974

17) Robertson, H. \& H. C. Polk, Jr.: The mechanism of infection in patients with diabetes mellitus. A review of leukocyte malfunction. Surgery 75:123 128, 1974

18) Saiki, O.; S. Negoro, I. Tsuyuguchi \& Y. Yamamura: Depressed immunological defense mechanisms in mice with experimentally induced diabetes. Infect. Immun. 28: 127 131, 1980

19) Obana, Y.; H. Ishiguro, M. Hoshiai, K. Hirata, Y. Yamamura, T. Nishino \& T. Tanino: The effects of ceftazidime (SN401) in experimental local infections in mice. Chemotherapy 31: 102 110, 1983 